\title{
PENGEMBANGAN DAYA TARIK WISATA BUDAYA DESA SLANGIT, CIREBON, JAWA BARAT
}

\author{
Altri Tiyar Barunawati dan Syamsul Alam Paturusi \\ Email: altritiyar@gmail.com dan syamsul_alam_paturusi@yahoo.fr
}

\begin{abstract}
Slangit is a village in Cirebon, West Java that has potentials to be used as a cultural tourist attraction. These potentials include tradition and custom ceremonies, traditional art of masks and mask performances. This article investigates the the development strategy of cultural attractions in the village of Slangit. Data collection are conducted by observation, in-depth interviews, and documentation. Data was analysed using a descriptive qualitative method and by using SWOT analysis. The result shows that the attempt to use arts potential as tourist attraction has been fairly developed by artists group but it is far from adequate because the lack of coordination between artists group and the authority responsible to promote culture and tourism. It is suggested that the government to work together with communities and artists to promote the village potentials as cultural tourism attractions both as away to preserve arts and to develop tourism as source of local economy.
\end{abstract}

Key words: development, cultural tourism attraction, the village of Slangit

\section{Pendahuluan}

Artikel ini membahas pengembangan potensi daya tarik wisata budaya di Desa Slangit, Cirebon, Jawa Barat dengan memfokuskan uraian pada potensi daya tarik wisata budaya serta strategi pengembangannya. Desa ini terletak di Kecamatan Klangenan, di mana desa ini mempunyai sesuatu keunikan tersendiri. Desa Slangit memiliki beberapa potensi wisata seperti berbagai program acara berupa upacara tradisi dan adat desa seperti, ngunjung buyut, mapag sri, sedekah bumi, mider atau raphet bumi, dengan dengan salah satunya melibatkan kesenian topeng sebagai ikon seni yang paling digemari oleh masyarakat dan wisatawan sebagai daya tarik wisata budaya. Permintaan yang pesat di industri pariwisata Cirebon menjadikan masyarakat, seniman Desa Slangit, dan instansi terkait dapat memanfaatkan 
peluang untuk mengembangkan daya tarik wisata budaya dengan melakukan beberapa event yang yang mengangkat tema kearifan budaya lokal.

Kunjungan wisatawan yang telah dicatat oleh Kantor Desa Slangit, pada tahun 2010-2014 mengalami peningkatan. Proses pencatatan kunjungan wisatawan yang dilakukan oleh Kantor Desa dilakukan dengan mengunjungi sanggar seni dan home industry yang ada di Desa Slangit dengan meminta data wisatawan yang datang. Pada tahun 2010 tercatat sebanyak 752 wisatawan, pada tahun 2010 wisatawan yang datang sebanyak 1034 orang. Pada tahun 2011, angka kunjungan wisatawan ke Cirebon menurun menjadi 946 orang. Penurunan kunjungan wisatawan ini terjadi dikarenakan pergantian sistem kepala pemerintahan desa. Namun, pada tahun 2012 wisatawan yang berkunjung mengalami peningkatan kembali sebanyak 1540 orang. Pada tahun 2013 kunjungan wisatawan mencapai 1875 orang dan pada tahun 2014 kunjungan wisatawan meningkat menjadi 2473 orang (Kantor Desa Slangit, 2015).

Daya tarik wisata budaya di Desa Slangit telah diupayakan peningkatan wisatawan dan minat generasi muda yang tinggi untuk mengangkat nilaifilosofi berupa atraksi wisata budaya dalam suatu acara kegiatan. Atraksi wisata budaya tersebut seperti, upacara mapag sri, ngunjung buyut, mider dan rapet bumi, sedekah bumi, selametan, dan sunatan. Hal ini dibuktikan dengan adanya partisipasi masyarakat sekitar khususnya para seniman. Mereka mulai menyadari keberadaan warisan budaya lokal seperti, seniman melakukan dan menghadiri event baik di Desa dan luar Desa, seniman bekerja sama dengan beberapa pihak sekolah melalui penerapan program pendidikan di luar sekolah (ekstra kulikuler) seni tari topeng di tingkat pendidikan SD dan SMP. Kegiatan ini rutin dilakukan sekali seminggu, Hal tersebut dilakukan guna menghindarkan eksplorasi budaya asing yang mulai masuk secara perlahan (Desa Slangit, 2015). Namun di sisi lain, banyak keluhan yang diinformasikan oleh para seniman seperti kurang mendapat dukungan secara penuh dari dinas terkait (Dinas Kebudayaan, Pariwisata, Pemuda dan Olahraga Kabupaten Cirebon) dalam mengayomi dan melestarikan daya tarik wisata budaya di Desa Slangit.

Melihat fenomena yang terjadi di lapangan belakangan ini, muncul beberapa permasalahan atau kesenjangan antara kenyataan dan harapan, yaitu disinyalir ada ketidakkeselarasan antara masyarakat, pihak seniman yang ada di Desa Slangit, dengan Dinas Kebudayaan Pariwisata Pemuda dan Olahraga, sehingga dikhawatirkan akan berpengaruh dan berdampak pada pengembangan daya tarik wisata budaya di Desa Slangit masa yang akan datang. Dalam kerangka pengembangan daya tarik wisata budaya di Desa Slangit masih diperlukan penelitian lebih lanjut, untuk menganalisis dan mengkaji fenomena tersebut. Permasalahan yang diangkat dalam penelitian ini adalah; pertama, apa potensi wisata budaya yang 
dikomodifikasikan sebagai daya tarik wisata budaya di Desa Slangit? Kedua, strategi pengembangan daya tarik wisata budaya apa saja yang yang akan direncanakan di Desa Slangit, Cirebon, Jawa Barat.

\section{Teori dan Metode}

Untuk membahas masalah dalam penelitian ini, terdapat dua teori yang sesuai untuk menjawab permasalahan tersebut yaitu komodofikasi dan teori perencanaan.

Pertama, teori komodifikasi yang diperkenalkan oleh Baudrillard (dalam Barker, 2004: 111), yang menjelaskan fenomena yang menjadikan apa yang semula tidak bernilai komersial lalu dijual sebagai komoditas untuk mendapatkan keuntungan ekonomi. Teori tersebut untuk melihat potensi daya tarik wisata budaya di Desa Slangit, dimana pada saat ini, upacara tradisi dan adat seperti ngunjung buyut, mapag sri, sedekah bumi, dan mider atau rapet bumi, yang melibatkan kesenian topeng Cirebon dalam upacara tradisi tersebut, mempunyai nilai jual bagi masyarakat maupun wisatawan dengan berbagai fungsi dan makna di dalamnya.

Kedua, teori perencanaan (Paturusi, 2008: 28) untuk mengetahui suatu proses pembuatan keputusan yang berkaitan dengan masa depan, dengan melihat unsur-unsur daya tarik wisata budaya yang telah dikomodifikasikan, dan mengambil langkah atau strategi pengembangan dari daya tarik wisata budaya seperti upacara tradisi dan adat ngunjung buyut, mapag sri, sedekah bumi, dan mider atau rapet bumi, dengan dilihat dari dimensi (sosial budaya, ekonomi, lingkungan dan seni) di Desa Slangit, Cirebon, Jawa Barat.

Metode penelitian yang digunakan adalah metode penelitian kualitatif, dengan teknik pengumpulan data dilakukan dengan observasi, wawancara mendalam, dan dokumentasi. Melalui pendekatan tersebut, faktor-faktor yang berkaitan dengan kajian potensi dan strategi pengembangan daya tarik wisata budaya di Desa Slangit, mempunyai nilai jual atau sudah menjadi komoditas masyarakat dan wisatawan secara mendalam. Pengambilan informan dilakukan dengan cara snowball sampling. Analisis dilakukan dengan menggunakan analisis deskriptif kualitatif terhadap data yang didapat di lokasi penelitian. Hasil analisis data secara keseluruhan, disajikan baik secara formal dan informal dalam bentuk foto, dan narasi atau penyataanpernyataan mengenai potensi, tabel mengenai strategi pengembangan daya tarik wisata budaya, yang mempunyai nilai jual di Desa Slangit, Cirebon, Jawa Barat.

\section{Potensi Budaya Desa Slangit}

Potensi yang ada di Desa Slangit adalah potensi ekologi dan nonekologi. Namun, yang ditekankan dalam hal ini adalah potensi non-ekologi, dimana seni budaya menjadi potensi utama sebagai daya tarik wisata dalam 
pengembangan Desa Slangit, khususnya kegiatan atau program acara upacara tradisi dan adat Desa.

Pertama, upacara tradisi dan adat di Desa Slangit saat ini telah mengalami transformasi dalam pelaksanaan upacara tradisi dan adat tersebut, dimana keterlibatan kesenian kesenian topeng di dalamnya telah menjadi komoditas bagi masyarakat dan wisatawan. Upacara adat dan tradisi budaya sebagai konsumsi bagi khalayak masyarakat dengan tidak hanya untuk kepentingan ritual, melainkan sebagai media hiburan rakyat. Upacara tradisi dan adat yang ada di Desa Slangit meliputi, upacara tradisi ngunjung buyut, mapag sri, sedekah bumi, mider atau rapet bumi. Berdasarkan keterangan dari salah satu pengelola sanggar seni Panji Asmara yang ada di Desa Slangit, Inu Kertapati, mengenai kesenian rakyat, seni topeng Cirebon dengan cepat telah mengalami transformasi. Inu Kertapati menjelaskan bahwa:

“... Proses transformasi telah mengalami perkembangan yang pesat hingga berakhir dengan keadaan yang sekarang. Perkembangan seni topeng dengan berbagai gerakan topeng Cirebon, sudah tersebar di berbagai wilayah seperti di daerah Losari, Slangit, Kreo, Palimanan dan lainnya. Acara pertunjukan seni topeng Cirebon di Desa Slangit mempunyai dua jenis pertunjukan, yaitu pertunjukan seni tari topeng sebagai pemeriah event seperti acara yang bersifat umum atau media hiburan semata (profan) dan acara pertunjukan seni topeng yang bersifat sakral, seperti upaara tradisi dan adat ...” (Wawancara, $24 \mathrm{Mei}$ 2015).

Kedua, potensi seni topeng di Desa Slangit juga mempunyai fungsi dan cerita yang terkandung di dalamnya. Pesan yang tersembunyi memiliki arti simbolik yang bila diterjemahkan sangat menyentuh berbagai aspek kehidupan, sehingga mempunyai nilai pendidikan. Tari topeng Cirebon dapat dijadikan media komunikasi untuk dimanfaatkan secara positif. Kepala tokoh masyarakat menjelaskan bahwa jauh sebelum masuk topeng ke Cirebon, tari topeng tumbuh dan berkembang sejak abad 10-11 Masehi. Kondisi atraksi wisata budaya, dengan menampilkan pertunjukan upacara tradisi dan adat serta kesenian topeng saat ini di Desa Slangit tidaklah begitu buruk, karena masih adanya keterlibatan dari masyarakat lokal dan beberapa sanggar tari topeng, dalam membantu pengembangan daya tarik wisata budaya di Desa Slangit. Bentuk dari keterlibatan seni topeng ini adalah rutin mengadakan upacara tradisi yang dilakukan warga desa dengan menghadirkan kesenian topeng, sebagai media untuk meminta izin kepada leluhur agar diberi kemudahan dan kelancaran pada saat upacara tradisi dan adat berlangsung, serta sebagai bentuk rasa syukur mereka atas apa yang sudah di dapatkan di dunia. Hadirnya atraksi wisata budaya seperti upacara tradisi dan adat, serta kesenian topeng di Desa Slangit, membuat wisatawan 


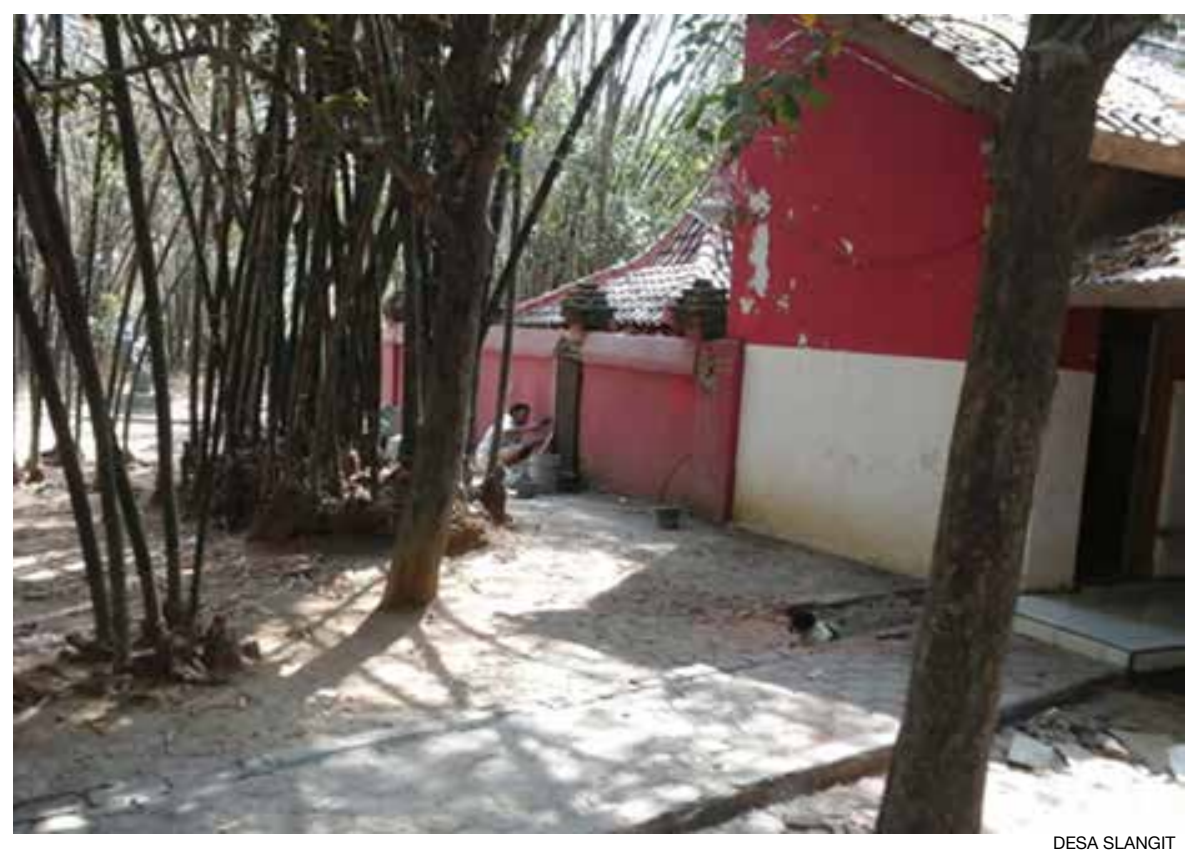

Foto 1. Makam keramat untuk upacara tradisi Ngunjung Buyut Desa di Slangit.

tertarik untuk melakukan kegiatan wisata di desa tersebut.

Ketiga, potensi atraksi seni topeng mempunyai dasar dan nilai yang tersirat didalamnya. Seni pertunjukan tari topeng di Desa Slangit, para seniman biasa menampilkan pertunjukan kepada wisatawan yang datang pada saat upacara tradisi dan adat di Desa Slangit, dengan menampilkan lima pokok topeng, seperti panji, samba, rumyang, tumenggung dan kelana.

Pada pernyataan yang telah dipaparkan melalui beberapa narasumber, terkait dengan acara pertunjukan topeng, fungsi dan cerita tari topeng, serta unsur dasar dan nilai yang tersirat dari seni topeng, pada saat program kegiatan upacara tradisi dan adat sebagai daya tarik wisata budaya di Desa Slangit, diperkuat pula oleh pernyataan yang dikemukakan dari pemikiran Karl Max dan George Sinnel (1992: 115) bahwa, komodifikasi potensi daya tarik wisata budaya yang ada di Desa Slangit, terdapat perubahan fungsi, yang awal mulanya pada zaman pengembangan seni topeng di Keraton Cirebon dijadikan sebagai syiar Islam, sekarang telah terjadi transformasi sebagai media hiburan dan upacara tradisi dana adat masyarakat. Hal tersebut dilakukan, dimana topeng yang semula menjadi salah satu media kepercayaan warga dalam mendapat kebahagiaan dan media kini termasuk untuk mencari nafkah.

Keempat, potensi daya tarik wisata budaya, berupa atraksi upacara tradisi dan adat Desa Slangit sangat beragam. Pada upacara tradisi dan adat yang terjadi di Cirebon, menemukan berbagai macam upacara baik upacara bagi kesuburan bumi seperti menanam padi, upacara menjaga keharmonisan 
hidup antar manusia dan alam raya, antara dunia nyata dengan dunia ghaib, upacara tradisi dalam menjaga kesehatan dan mencari kesembuhan maupun upacara ritus lintas lainnya. Upacara tradisi yang biasa dilakukan di Desa Slangit, dimana seni topeng dijadikan sebagai media daya tarik wisata budaya, diantaranya Ngunjung Buyut (Foto 1)

Ngunjung Buyut adalah ritual tahunan mengunjungi makam para leluhur, yang ada di petilasan atau makam nenek moyang terdahulu. Ngunjung Buyut ini dilakukan oleh warga sekitar. Buyut atau nenek moyang masyarakat setempat adalah orang-orang yang dianggap suci dan telah berjasa menyebarkan agama Islam ke Desa Slangit, menjadi kyai atau ki dan membuka pesantren serta menurunkan anak cucunya di Desa slangit.

Pengelola Sanggar seni topeng Panji Asmara, Inu Kertapati menjelaskan bahwa:

“... Prosesi upacara tradisi ngunjung buyut di Desa Slangit, dimulai dengan arak-arakan warga dengan membawa makanan dari warga sekitar, yang dilakukan sejak pagi berkeliling melalui sekitar perkampungan Desa Slangit. Ngunjung buyut dimulai dengan upacara membersihkan makam dan membersihkan pusaka. Selain itu, pertunjukan wayang kulit atau wayang golek, seni topeng, arak-arakan (dengan mempertujukan figur binatang fiktif), dan doa bersama menjadi pemanis atau pelengkap dari upacara tradisi ini. Upacara tradisi ngunjung buyut ini mempunyai makna yang mendalam, sehingga mampu mendatangkan wisatawan yang datang, karena disamping mempunyai fungsi spiritual sebagai upacara ritus lintas, tetapi juga mempunyai fungsi sosial yaitu dapat mempererat tali persaudaraan antar anggota keturunan ...” (Wawancara, 25 Mei 2015).

Mider dan Rapet adalah sebuah ritus lintas yang sudah dilaksanakan berabad-abad oleh masyakat Desa Slangit, yaitu merupakan upacara dalam menyambut musim tanam. Upacara ini telah banyak dipengaruhi oleh sistem kepercayaan masyarat lokal, yang merupakan sinkritisme dengan agama Hindu dan Islam.

Salah satu tokoh masyarakat, Muhaimin Za menjelaskan bahwa Mider mempunyai arti keliling, di mana upacara ini dilaksanakan oleh ketua adat dan kepala desa berkeliling di kebun dan sawah warga Desa Slangit, untuk melihat kebun dan sawahnya yang sudah dibersihkan, diolah dan siap ditanami. Apabila kebun dan sawah sudah siap ditanami dan di panen, ketua adat dan kepala desa memperhatikan tanda-tanda alam sekitar Desa Slangit. Ketua adat dan kepala desa berangkat ke makan leluhur dan makan Sunan Gunung Jati untuk melaksanakan doa dan mengambil air dari makam tersebut. Setelah itu, upacara rapet bumi ini resmi musim tanam bisa di mulai. Muhaimin Za juga menambahkan: 

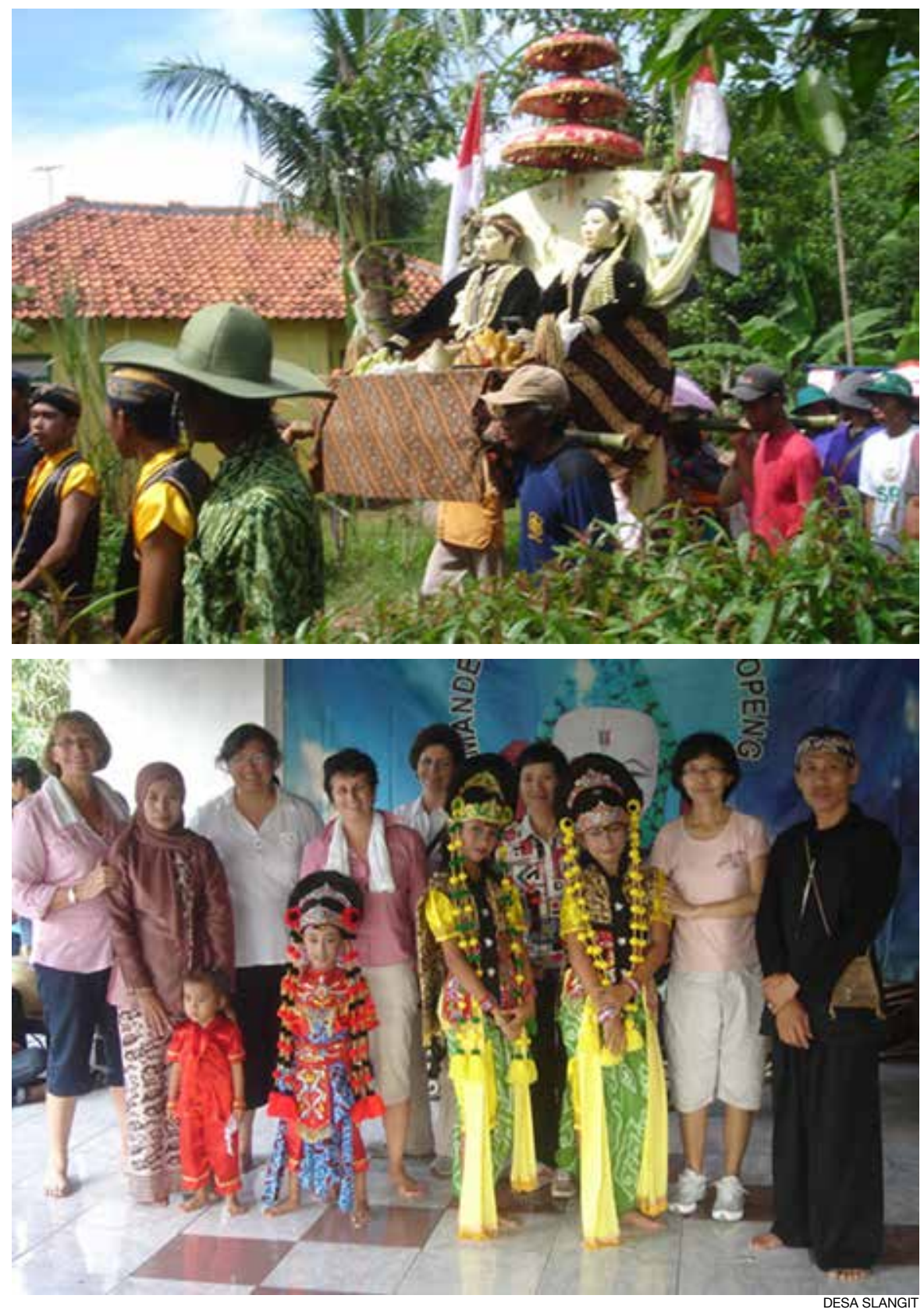

Foto 2 dan 3. Upacara Tradisi Mapag Sri dan wisatawan asing ke Sanggar Panji Asmara pada saat upacara tradisi Mapag Sri.

“... Upacara musim tanam ini, diadakan upacara ritual untuk para leluhur, yang mana seni topeng menjadi media sebagai sarana meminta ijin kepada leluhur dalam proses tanamnya. Air yang diambil dari makam Sunan Gunung Jati sebagai simbolik pemberi kesuburan tanah, sehingga diharapkan hasil 
tanam warga mendapatkan hasil yang terbaik, upacara mider ini dilaksanakan pada bulan-bulan menjelang musim hujan yaitu sekitar bulan Oktober, November dan Desember ...” (Wawancara, 26 Mei 2015).

Mapag sri memiliki arti menjemput roh Dewi Sri agar memberikan berkah pada hasil panen yang didapatkan oleh petani. Para petani Desa Slangit hingga saat ini masih memegang sisa-sisa kepercayaan Hindu, yaitu dengan mempercayai adanya Dewi Sri sebagai pelindung tanaman dan pertanian. Dewi Sri disebut juga dengan nama Dewi Pohaci atau Dewi Padi (Foto 2 dan 3).

Salah seorang kepala Dusun Slangit yang bernama Atas Maulana menerangkan bahwa, upacara mapag sri mengambil waktu hingga tiga hari. Atas Maulana menambahkan bahwa:

“... Hari pertama adalah hari dimana ketua adat dan kepala desa serta anggota masyarakat lainnya, melaksanakan kunjungan ke makam leluhur, di hari ke dua dilaksanakan arak-arakan atau festival keliling kampung untuk mengarak boneka Dewi Sri. Pada hari ketiga diadakan acara hiburan seperti kesenian tari topeng sepanjang hari, dan pada malam harinya dilaksanakan slametan atau doa dan pertunjukan topeng selama semalam suntuk ..." (Wawancara, $26 \mathrm{Mei}$ 2015).

Sedekah bumi adalah tradisi yang dilaksanakan masyarakat Desa Slangit dalam ungkapan berterima kasih kepada Sang Pencipta yang telah memberikan kehidupan dan hasil panen yang berlimpah. Masyarakat sangat antusias menyambut upacara ini, banyak wisatawan datang untuk melihat upacara tradisi tersebut (Foto 4).

Salah seorang penari topeng yang ada di Sanggar Panji Asmara yang bernama Etty Kurniawaty menerangkan bahwa upacara dilakukan pada setiap tahun di bulan-bulan musim panen yaitu sekitar bulan Oktober. Dalam wawancara, Etty Kurniawaty menjelaskan bahwa:

“... Masyarakat mengirim hasil buminya kepada kepala desa atau kepada keraton (semua hasil kebun yang terpendam seperti, ubi talas, kembili dan kentang) dan sura gumantang (buah-buahan dan sayur-sayuran). Selain itu, ada juga hasil ternak seperti ayam, bebek, kambing, kerbau dan sapi ...” (Wawancara, 26 Mei 2015)

Pada pernyataan yang telah dipaparkan melalui beberapa narasumber terkait dengan upacara tradisi yang ada di Desa Slangit sebagai daya tarik wisata, seni topeng saat ini telah memiliki fungsi lain yaitu dapat dijadikan sebagai media atau sarana dalam meminta izin kepada para leluhur yang 


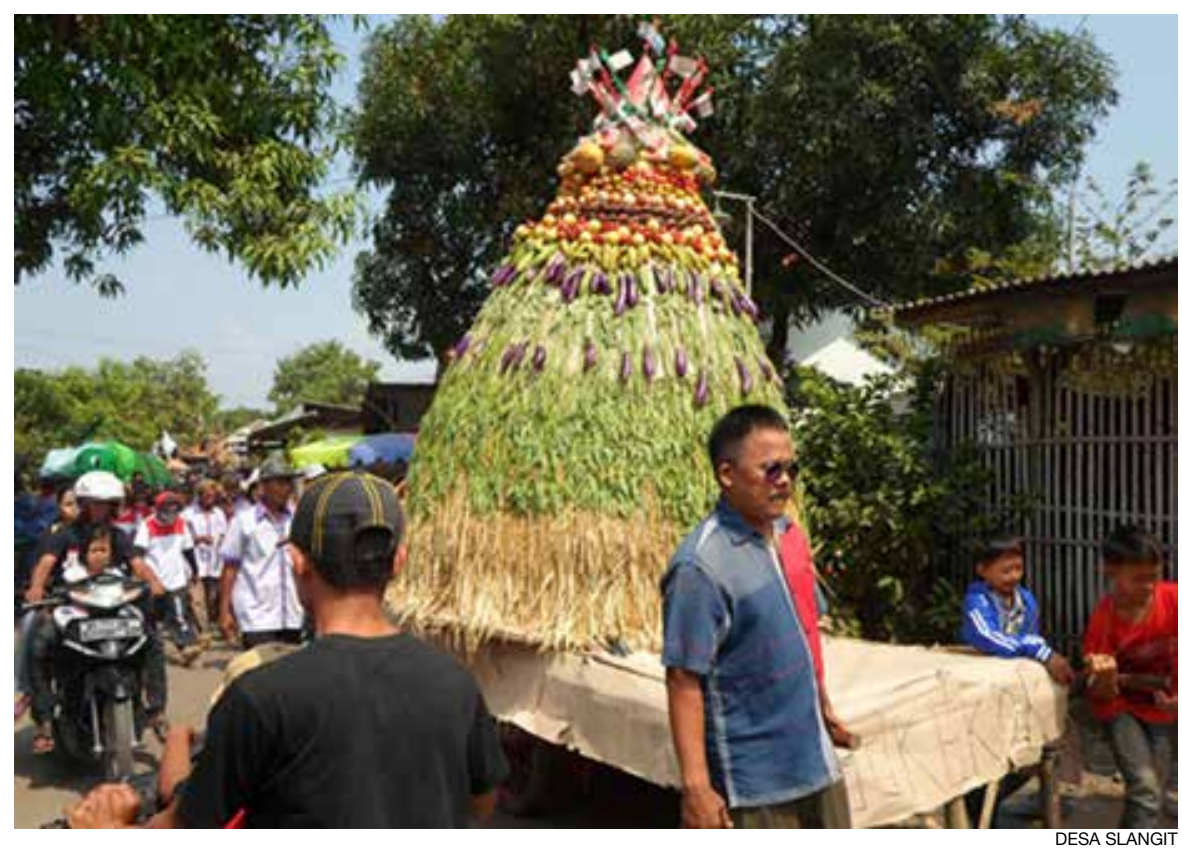

Foto 4. Upacara Tradisi Sedekah Bumi di Desa Slangit.

telah tiada. Masyarakat mempercayai dengan adanya ritual sebelum upacara-upacara tersebut dimulai, diharapkan dapat diberi kelancaran dan hasil yang terbaik.

Pernyataan tersebut, sesuai dengan yang dikemukakan Baudrillard (dalam Barker, 2004: 111) bahwa objek dalam masyarakat konsumen tidak lagi dinilai sebagai nilai guna, melainkan sebagai komoditas tanda dalam suatu masyarakat yang ditandai oleh komodifikasi yang semakin meningkat. Peningkatan komodifikasi tersebut ditandai dengan konsumsi yang lebih besar atau konsumsi tanda, yang melekat pada pertumbuhan komoditas kebudayaan, pemasaran celah pasar tertentu dan penciptaan gaya hidup.

Upacara tradisi yang dilakukan oleh warga Desa Slangit telah berubah menjadi komoditas atau konsumsi warga desa sebagai bagian dari gaya hidup, sehingga berbagai macam upacara tradisional yang unik dan menarik berangsur-angsur telah menjadi perhatian wisatawan. Mereka dapat mengenal lebih jauh kebudayaan yang tidak hanya di pusat Cirebon, melainkan tradisi dan kehidupan di Desa Slangit.

\section{Strategi Pengembangan Daya Tarik Wisata Slangit}

Strategi pengembangan daya tarik wisata budaya harus ditunjang dengan program-program pengembangan yang baik. Pengembangan daya tarik wisata budaya ini diharapkan dapat memberikan sumbangsih secara berkelanjutan. Model pengembangan ini, didasarkan pada pengembangan 
Tabel 1. Analisis SWOT Strategi Pengembangan Daya Tarik Wisata Budaya di Desa Slangit

\begin{tabular}{|c|c|c|}
\hline & Kekuatan (Strength) & Kelemahan (Weakness) \\
\hline $\begin{array}{l}\text { IFAS } \\
\text { (Internal Factor Analysis } \\
\text { Summary) }\end{array}$ & $\begin{array}{l}\text { a. Dimensi Sosial Budaya } \\
\text { - Masyarakat mempunyai } \\
\text { interaksi yang baik dalam } \\
\text { gotong royong dan toler- } \\
\text { ansi yang kuat. } \\
\text { - Masyarakat memegang } \\
\text { adat dan kepercayaan. } \\
\text { - Menjaga dan melestarikan } \\
\text { warisan budaya lokal. } \\
\text { b. Dimensi Ekonomi } \\
\text { - Menciptakan lapangan } \\
\text { kerja, bekerja sama den- } \\
\text { gan LSM yang ada. }\end{array}$ & $\begin{array}{l}\text { a. Dimensi Sosial Budaya } \\
\text { - Kesadaran masyakarakat } \\
\text { terhadap kelestarian } \\
\text { program acara kesenian } \\
\text { tradisional dan upacara } \\
\text { tradisi budaya lokal. } \\
\text { - Komunikasi antara } \\
\text { masyarakat, aparat desa } \\
\text { dan pemerintah setempat } \\
\text { mengenai program acara } \\
\text { kesenian tradisional dan } \\
\text { upacara tradisi budaya } \\
\text { lokal. }\end{array}$ \\
\hline $\begin{array}{l}\text { (EFAS) } \\
\text { (Eksternal Factor Analysis } \\
\text { Summary) }\end{array}$ & $\begin{array}{l}\text { c. Dimensi Lingkungan } \\
\text { - Lahan tanah yang subur } \\
\text { - Aliran sungai yang jernih. } \\
\text { d. Dimensi Seni } \\
\text { - Pengembangan daya tarik } \\
\text { wisata budaya melalui } \\
\text { sanggar seni yang ada di } \\
\text { Desa Slangit }\end{array}$ & $\begin{array}{l}\text { b. Dimensi Ekonomi } \\
\text { - Kesadaran masyakat } \\
\text { terhadap pengembangan } \\
\text { daya tarik wisata budaya } \\
\text { Cirebon yang dapat men- } \\
\text { jadikan komoditas bagi } \\
\text { Desa Slangit. } \\
\text { c. Dimensi Lingkungan } \\
\text { - Fasilitas Di Desa Slangit. } \\
\text { d. Dimensi Seni } \\
\text { - Sarana dan prasarana } \\
\text { dalam kegiatan daya tarik } \\
\text { wisata budaya di Desa } \\
\text { Slangit. }\end{array}$ \\
\hline Peluang (Opportunities) & $\begin{array}{c}\text { Strategi SO } \\
\text { (Strength Opportunities) }\end{array}$ & $\begin{array}{c}\text { Strategi WO } \\
\text { (Weakness Opportunities) } \\
\end{array}$ \\
\hline $\begin{array}{l}\text { a. Dimensi Sosial Budaya } \\
\text { - Pengembangan destinasi } \\
\text { berbasis alam dan budaya } \\
\text { di Cirebon. } \\
\text { - Minat wisatawan terhadap } \\
\text { daya tarik wisata budaya. } \\
\text { b. Dimensi Ekonomi } \\
\text { - Pengembangan IT (Infor- } \\
\text { masi Teknologi) di Kota } \\
\text { dan Kabupaten Cirebon } \\
\text { semakin pesat. } \\
\text { - Pengembangan tol Cipali } \\
\text { (Cikampek-Palimanan). } \\
\text { - Pembangunan dan } \\
\text { pengembangan Bandara } \\
\text { Kertajati. } \\
\text { - Promosi Travel Agent. } \\
\text { - Berkembangnya sekolah } \\
\text { pariwisata. } \\
\text { c. Dimensi Lingkungan } \\
\text { - Berkembangnya wisata } \\
\text { berbasis alam. } \\
\text { d. Dimensi Seni } \\
\text { - Kegiatan atraksi wisata } \\
\text { budaya mendatangkan } \\
\text { keuntungan warga sekitar. }\end{array}$ & $\begin{array}{l}\text {-Mengadakan kerjasama } \\
\text { dengan pemerintah dan } \\
\text { lembaga pariwisata untuk } \\
\text { melakukan promosi dan } \\
\text { pemasaran. } \\
\text { - Bekerjasama melakukan } \\
\text { pembangunan sarana dan } \\
\text { prasarana pendukung. }\end{array}$ & $\begin{array}{l}\text { - Memberikan kesadaran } \\
\text { kepada masyarakat akan } \\
\text { pentingnya menjaga be- } \\
\text { bersihan lingkungan. } \\
\text { - Memberikan pendidikan } \\
\text { kepada masyarakat yang } \\
\text { terkait dengan ilmu pari- } \\
\text { wisata. }\end{array}$ \\
\hline
\end{tabular}




\begin{tabular}{|c|c|c|}
\hline Ancaman (Threats) & $\begin{array}{c}\text { Strategi ST } \\
\text { (Strength Threats) }\end{array}$ & $\begin{array}{c}\text { Strategi WT } \\
\text { (Weakness Threats) }\end{array}$ \\
\hline $\begin{array}{l}\text { a. Dimensi Sosial Budaya } \\
\text { - Perubahan budaya lokal. } \\
\text { - Masyarakat lokal menjadi } \\
\text { individualis. } \\
\text { b. Dimensi Ekonomi } \\
\text { - Investor Dalam Negeri } \\
\text { dan Luar Negeri yang } \\
\text { semakin berkembang. } \\
\text { - Tenaga kerja dari luar } \\
\text { daerah Cirebon. } \\
\text { c. Dimensi Lingkungan } \\
\text { - Polusi Lingkungan. } \\
\text { - Fasilitas Desa yang tidak } \\
\text { terjaga. } \\
\text { d. Dimensi Seni } \\
\text { - Pembangunan dan } \\
\text { pengembangan kegiatan } \\
\text { seni tradisional, yang } \\
\text { bekaitan dengan pariwisa- } \\
\text { ta budaya masih dilaku- } \\
\text { kan di pusat Kota dan } \\
\text { Kabupaten Cirebon. }\end{array}$ & $\begin{array}{l}\text { - Memberikan penjelasan } \\
\text { yang lengkap tentang } \\
\text { upacara tradisi dan adat } \\
\text { sebagai daya tarik wisata } \\
\text { di Desa Slangit. } \\
\text { - Menjaga kelestarian } \\
\text { lingkungan. }\end{array}$ & $\begin{array}{l}\text { - Melakukan perbaikan } \\
\text { fasilitas-fasilitas pariwisa- } \\
\text { ta. }\end{array}$ \\
\hline
\end{tabular}

kegiatan kawasan daya tarik wisata budaya di Desa Slangit dan sekitarnya serta penggabungan hasil analisis SWOT, seperti adanya strategi pengembangan daya tarik wisata budaya melalui beberapa dimensi (dimensi sosial budaya, dimensi ekonomi, dimensi lingkungan dan dimensi seni) dengan melihat dari kekuatan (strengths), kelemahan (weakness), peluang (opportunity), dan ancaman (threats)

Strategi pengembangan daya tarik wisata budaya di Desa Slangit, dilihat dari kekuatan (strength) yaitu adanya interaksi yang baik dalam gotong royong dimana toleransi yang kuat antarmasyarakat dan mereka masih memegang adat dan kepercayaan setempat. Selain itu, Desa Slangit dapat menciptakan lapangan pekerjaan, bekerjasama dengan LSM yang ada di Desa Slangit). Desa Slangit juga mempunyai lahan tanah yang subur, aliran sungai yang jernih yang sering dimanfaatkan sebagai kegiatan atraksi acara tradisi dan adat. Pengembangan daya tarik wisata budaya dapat dilakukan kerjasama melaui sanggar-sanggar seni yang ada di Desa Slangit.

Strategi pengembangan daya tarik wisata budaya di Desa Slangit, dilihat dari kelemahan (weakness) yaitu lemahnya kesadaran masyakarakat akan kelestarian program acara upacara tradisi budaya lokal, kurangnya komunikasi antara masyarakat, aparat desa dan pemerintah setempat mengenai program upacara tradisi budaya lokal, kurangnya kesadaran masyakat akan atraksi wisata budaya, seperti upacara tradisi dan adat Cirebon yang dapat menjadikan komoditas bagi Desa Slangit, terbatasnya fasilitas yang ada di Desa Slangit, minimnya sarana dan prasarana dalam 
kegiatan daya tarik wisata budaya di Desa Slangit.

Strategi pengembangan daya tarik wisata budaya di Desa Slangit, dilihat dari peluang (opportunity) yaitu adanya pengembangan destinasi berbasis alam dan budaya di Kabupaten Cirebon serta minat yang kuat dari wisatawan terhadap daya tarik wisata budaya. Di samping itu, untuk meningkatkan kunjungan wisatawan diperlukan pengembangan IT/Informasi Teknologi di Kota dan Kabupaten Cirebon. Jalan tol Cikampek-Palimanan, pembangunan dan pengembangan Bandara Nasional Kertajati, promosi travel agent dan sekolah pariwisata dapat membuka peluang dalam mengembangkan daya tarik wisata budaya di Desa Slangit. Kesenian topeng dan seni tradisional lainnya, merupakan bagian dari daya tarik wisata budaya yang dapat mendatangkan keuntungan bagi warga sekitar.

Strategi pengembangan daya tarik wisata budaya di Desa Slangit, dilihat dari ancaman (threats) yaitu dikhawairkan terjadi perubahan budaya lokal dan masyarakat lokal menjadi sangat individualis, masuk dan berkembangnya investor dalam negeri dan luar negeri dengan membawa tenaga kerja dari luar daerah Cirebon, terjadi polusi lingkungan dan fasilitas desa yang tidak terjaga, serta pembangunan dan berkembangnya daya tarik wisata budaya yang di pusat kota dan Kabupaten Cirebon.

Strategi pengembangan daya tarik wisata budaya di Desa Slangit berdasarkan analisis SWOT, dengan strategi SO (Strength Opportunity) yaitu bekerja sama dengan pemerintah dan lembaga pariwisata untuk melakukan promosi dan pemasaran, bekerja sama melakukan pembangunan sarana dan prasarana pendukung dalam pengembangan seni topeng di Desa Slangit. Strategi WO (Weakness Opportunities) yaitu memberikan kesadaran kepada masyarakat akan pentingnya menjaga dan melestarikan seni budaya serta lingkungannya dan memberikan arahan akan dampak rusaknya bila tidak dijalankan dengan baik, memberikan pelatihan pendidikan kepada masyarakat yang terkait dengan ilmu pariwisata, Strategi ST (Strength Threat) yaitu memberikan penjelasan yang lengkap tentang daya tarik seni topeng dan potensi lainnya yang ada di Desa Slangit, tidak mencemari polusi/menjaga lingkungan di sekitar Desa Slangit, Strategi WT (Weakness Threats) yaitu melakukan perbaikan fasilitas pariwisata. Hasil analisis SWOT, dituangkan dalam Tabel 1.

Desa Slangit memiliki daya tarik wisata budaya yang beraneka ragam. Daya tarik seni budaya khususnya, dalam pengembangan daya tarik wisata budaya membutuhkan keterlibatan masyarakat lokal. Keterlibatan masyarakat lokal ini, dapat dijalankan dari segi perencanaan, pengembangan, pengelolaan, dan evaluasi. Pengembangan daya tarik wisata budaya dihadirkan dengan berbagai program pengembangan kegiatan pariwisata budaya, melalui upacara tradisi dan adat serta seni topeng agar dapat dinikmati oleh semua orang secara berkelanjutan. 
Pengembangan daya tarik wisata budaya di Desa Slangit memiliki permasalahan dan kendala baik secara fisik dan non fisik, sehingga membutuhkan program-program pengembangan yang tepat dan terciptanya kegiatan daya tarik wisata budaya yang berkelanjutan. Untuk itu, strategi pengembangan pengembangan daya tarik wisata budaya juga, yang memerlukan strategi pendekatan berdasarkan 4A (attraction, acess, amenities, ancillary service). Program atraksi wisata budaya yang ada di Desa Slangit meliputi program pengembangan atraksi wisata budaya ngunjung buyut, program pengembangan atraksi wisata budaya mider atau raphet bumi, program pengembangan atraksi wisata budaya Mapag Sri, program pengembangan atraksi wisata budaya Sedekah Bumi, aksesibilitas (program perbaikan jalan, program peningkatan transportasi), amenities (program pembangunan hotel dan restaurant, program pembangunan fasilitas umum) dan layanan kelembagaan /anciallary service (program pelatihan kepada masyarakat untuk meningkatkan kualitas sumber daya manusia, program promosi dan pemasaran, program peningkatan keamanan).

Pernyataan yang telah dipaparkan melalui beberapa narasumber, terkait dengan strategi pengembangan daya tarik wisata budaya di Desa Slangit, Cirebon, Jawa Barat, diperkuat juga dengan pernyataan yang dikemukakan oleh Paturusi (2008: 28) bahwa perencanaan pariwisata merupakan suatu proses pembuatan keputusan yang berkaitan dengan masa depan suatu daerah tujuan wisata, atau atraksi wisata yang merupakan suatu proses dinamis penentuan tujuan, yang secara sistematis mempertimbangkan berbagai alternatif tindakan untuk mencapai tujuan, implementasi terhadap alternatif terpilih dan evaluasi. Proses perencanaan pariwisata dengan melihat lingkungan fisik, ekonomi, sosial, politik sebagai suatu komponen yang saling terkait dan saling tergantung satu dengan lainnya.

Upacara tradisi dan adat di Desa Slangit, mempunyai strategi dalam mengembangkan beberapa potensinya sebagai daya tarik wisata budaya. Strategi program pengembangan ini, dapat dianalisis dalam bentuk SWOT yang terdiri dari kekuatan, peluang, kelemahan dan ancaman, dimana tiap analisis SWOT tersebut mempunyai proses perencanaan pariwisata yang dilihat dari dimensi sosial budaya, ekonomi, lingkungan dan dimensi seni. Di samping itu, pernyataan yang dikemukakan oleh Cooper (1993: 84) bahwa suatu destinasi atau daya tarik wisata yang unggul dalam menciptakan pengalaman wisatawan, dapat digambarkan dengan adanya unsur 4 A yaitu attraction, accesibility, amenities, dan anciallary service.

Desa Slangit mempunyai potensi yang terdiri dari beberapa program atraksi (produk utama sebuah destinasi, berkaitan dengan apa yang bisa kita lihat dan lakukan di destinasi tersebut seperti program upacara tradisi ngunjung buyut, sedekah bumi dan lainnya), aksesibilitas (sarana dan infrastruktur untuk menuju destinasi, seperti akses jalan raya, ketersediaan 
sarana transportasi dan rambu-rambu penunjuk jalan, seperti keadaan jalan menuju Desa Slangit, jasa angkutan menuju Desa dan petunjuk jalan lainnya), amenities (fasilitas pendukung menuju Desa Slangit, seperti rumah makan, penginapan rest area, tempat parkir, klinik kesehatan, dan sarana ibadah, sarana pendukung yang masih minim di Desa Slangit yaitu letak restaurant atau rumah makan serta penginapan yang masih jauh dari destinasi wisata), dan anciallary service/layanan kelembagaan (ketersediaan sebuah organisasi atau orang-orang yang mengurus destinasi tersebut, dalam pengembangan daya tarik wisata budaya di Desa Slangit belum mempunyai kelembagaan yang serius menanganinya, lembaga atau organisasi yang membantu dalam program pengembangan daya tarik wisata budaya, seperti pihak desa, sanggar dan beberapa home industry yang ada di Desa Slangit).

\section{Penutup}

Berdasarkan hasil analisis di atas maka dapat disimpulkan hal-hal sebagai berikut. Pertama, Desa Slangit mempunyai potensi yang berkaitan dengan upacara tradisi dan adat seperti mapag sri, ngunjung buyut, mider dan rapet bumi, sedekah bumi dimana seni topeng bagian dari prosesi upacara tradisi dan adat tesebut memiliki daya tarik yang kuat sebagai daya tarik wisata budaya. Pada saat ini, seni topeng di Desa Slangit biasanya dipentaskan pada acara yang bersifat umum atau hiburan dan upacara tradisi (sakral). Adapun seni topeng yang dilakukan pada acara umum atau hiburan seperti, hajatan, selametan, sedangkan, acara yang dilakukan pada saat upacara tradisi (sakral) dengan melibatkan seni topeng seperti, mapag sri, ngunjung buyut, mider dan rapet bumi, sedekah bumi.

Potensi daya tarik wisata budaya di Desa Slangit, berjalan dengan baik, namun pengembangan potensi seni budaya tidak berjalan dengan maksimal. Hal ini berkaitan dengan kurangnya sinkronisasi antara pihak pengelola sanggar kesenian yang ada di sanggar Desa Slangit, dengan Dinas Pariwisata, Kebudayaan, Pemuda dan Olahraga Kabupaten Cirebon, yang berkaitan pengembangan daya tarik wisata budaya di Desa Slangit seperti komunikasi yang tidak berjalan dengan baik dan tidak ada dukungan penuh dari sarana dan prasarana.

Kedua, pengembangan senitopeng telah mempunyainilaijual(komoditas) untuk di konsumsi. Proses upacara tradisi dan adat Desa Slangit, yang mana proses komodifikasi pada saat ini, sudah dapat dikonsumsi oleh wisatawan untuk keperluan hiburan selain sebagai prosesi ritual. Selain itu, atraksi upacara tradisi dan adat juga, melibatkan seni topeng salah satunya sebagai media untuk meminta izin kepada leluhur agar diberikan kelancaran dan kemudahan pada saat prosesi upacara tradisi dan adat berlangsung. Durasi pertunjukan seni topeng pada upacara tradisi, yang awal mulanya dilakukan 
selama 1 sampai 2 jam, namun pada saat ini hanya dipertujukan $\pm 1 / 2$ jam saja, mengingat agar penonton atau wisatawan tidak merasa jenuh.

Daya tarik wisata budaya yang dikomodifikasikan di Desa Slangit membutuhkan strategi pengembangan di dalamnya, dimana terdapat beberapa program yang telah dilaksanakan untuk menarik wisatawan yang datang mulai dari perencanaan yang matang, pembinaan SDM, promosi dan pemasaran.

\section{Ucapan Terimakasih}

Penulis menyampaikan terima kasih kepada Prof. Dr. I. Nyoman Darma Putra, M. Litt, selaku Ketua Program Studi Magister Kajian Pariwisata Universitas Udayana sekaligus pembimbing I dan Dr. Ir. Syamsul Alam Paturisi, MSP, selaku Sekertaris Program Studi Magister Kajian Pariwisata Universitas Udayana sekaligus pembimbing II. Terima kasih setulus-tulusnya penulis sampaikan kepada Ibu dan Bapak penulis serta seluruh keluarga yang sudah memberikan dorongan dan motivasi sehingga terselesaikannya artikel ini. Di samping itu juga, ucapan terima kasih yang setulusnya kepada beberapa teman-teman yang sudah memberikan bantuan dan inspirasi dalam penulisan artikel ini.

\section{Daftar Pustaka}

Barker, Chris. 2004. Cultural Studies: Teori \& Praktik. (Nurhadi, Penj). Yogyakarta: Kreasi Wacana.

Cooper, Chris, Fletcher, John., Gilbert, David and Wanhill, Stephen. 1993. Tourism Principles \& Practice, UK: PITMAN

Paturusi, Syamsul Alam, 2008. Perencanaan Kawasan Pariwisata. Denpasar: Udayana Press.

Rizter, George dan Douglas J. Goodman. 2004. Teori Sosiologi Modern. (Alimandan, Pentj). Jakarta: Prenada Media.

\section{Profil penulis}

Altri Tiyar Barunawati, S.Par. M.Par menyelesaikan pendidikan Magister Magister Kajian Pariwisata di Universitas Udayana Denpasar angkatan 2015. Ia menyelesaikan program studi ekstensi S1 pada tahun 2012 di Fakultas Pendidikan jurusan Manajemen Resort and Leisure, Ilmu Pendidikan Sosial di Universitas Pendidikan Indonesia Bandung, kemudian ia juga menyelesaikan program studi Diploma III pada tahun 2010 di Fakultas Ilmu Bahasa jurusan Usaha Perjalanan Wisata, di Universitas Padjadjaran Bandung. Altri pernah bekerja di salah satu travel agent "La Jere" tour and travel yang berlokasi di Bandung dalam bidang tour leader untuk melayani, mendampingi memberikan informasi kepada wisatawan yang akan berkunjung dan memakai jasa La Jere tour and travel ke berbagai destinasi wisata.

Dr. Ir. Syamsul Alam Paturusi, MSP adalah dosen Prodi Magister Kajian Pariwisata, 
saat ini menjabat sebagai sekertaris program studi Magister Kajian Pariwisata, Universitas Udayana. Selain itu, beliau juga aktif mengajar sebagai dosen Magister Teknik Arsitektur di Universitas Udayana, Denpasar, Bali. Beliau berasal dari Makassar, Sulawesi Selatan, yang lahir dan dibesarkan di keluarga besar Paturusi. Program pendidikan yang sudah ditempuh yaitu Sarjana (S1) di Arsitektur Universitas Hasanuddin, Makassar, jenjang Magister (S2) di PWK ITB, Bandung, dan jenjang Doktor $\left(\mathrm{S}_{3}\right)$ di Université de Pau et des Pays de l>Adour, Prancis. 